\title{
The Impact on The Implementation of Presidential Regulation Number 20 of 2018 Concerning The Use of Immigrant Worker
}

\author{
Muhammad Irfan Nur Fahmi ${ }^{1}$; Nasrullah ${ }^{2}$ \\ ${ }^{1,2}$ Program Studi Hukum, Fakultas Hukum, Universitas Muhammadiyah Yogyakarta, Indonesia \\ *Corresponent Author: irfaanurf@gmail.com
}

\section{Info of Article}

Submitted: 03-02-2020

Reviewed: 28-02-2020

Revised: 30-03-2020

Accepted: 31-03-2020

DOI: $10.18196 / \mathrm{mls} . v 2 i 2.11492$

\begin{abstract}
In regulating the constitutional order, it should have a clear legal basis based on the viewpoint of a democratic political system. With the issuance of Presidential Regulation Number 20 of 2018 concerning the Use of Immigrant Worker, it is hoped that it can become a government effort in overcoming problems in the availability of jobs for domestic workers, this is due to the use of immigrant workers which has an impact on domestic worker in Indonesia and deviant articles and not in
\end{abstract} accordance with what is contained in this rule. Therefore, the issuance of this Presidential Regulation discusses licensing and regulations that must be obeyed and implemented by both employers and workers themselves. It is the same as entering the new normal era which is caused by the existence of the Covid-19 and become pandemic; so that permits for the entry and exit of immigrant workers into Indonesia must be clearer and stronger, in order to minimize the movement and spread of the virus. This study used qualitative research with a normative juridical case approach, this study also was conducted to analyze how the Presidential Regulation Number 20 of 2018 gave impacts especially to the domestic worker caused by stipulated this regulation; not only that, this study also discussed the mechanism of monitoring and evaluating this presidential regulation. The results of this research showed that there was some impacts caused by the existence of the Presidential Regulation Number 20 of 2018 both from the use and licensing of immigrant workers as well as from the articles contained in this regulation.

Keyword: immigrant workers, regulation, investment.

\section{Introduction}

The country of Indonesia as the traffic of the struggle of domestic workers and immigrant workers to increase dignity, starting from the demands of increasing wages, justice and working hours already voiced from various parts of the country. Ironically, when Indonesian workers fight for their rights and justice, the government seems to close their ears as if they did not hear the shout.

With the Presidential Regulation No. 20 of 2018 concerning the Use of Immigrant Workers, still presents problems in the community and the government. Some people are concerned that simplifying the permits of foreigners working in Indonesia will increase unemployment. Susilo Andi Darma said that so far, the government was not consistent with the Law Number 13 of 2003. ${ }^{1} \quad$ Then, what about the implications of

\footnotetext{
1 Fiki, Ariyanti “Ada Aturan Baru Tenaga Kerja Asing, Nasib Pekerja RI di Ujung Tanduk" https://www.liputan6.com/bisnis/read/3469874/ada-aturan-baru-tenaga-kerja-asing-nasib-pekerja-ri-diujung-tanduk accessed on 09 June 2018, 21.00
} 
adding the Presidential Decree No. 20 of 2018, the reason for not facilitating the entry of immigrant workers, but to simplify the permission of foreigners working in Indonesia.

The Presidential Regulation No. 20 of 2018 is presented not to defend the interests of Indonesian workers. In fact, if it is examined more, in the constitution of the Republic of Indonesia the government should defend the lives of Indonesian citizens. The 1945 Constitution gives a mandate to the government to fulfill the rights of citizens to employment and decent livelihoods such as the sound of Article 27 paragraph (2) of the 1945 Constitution, that "every citizen has the right to work and a decent livelihood for humanity". That is, the Presidential Regulation clearly injures the mandate of the 1945 Constitution.

There are some contradictions in the Presidential Regulation Number 20 Year 2018 with The Labor Law Number 13 of 2003. First in Article 9 of the Presidential Regulation No. 20 of 2018. The article states, "... the ratification of the plan to use immigrant workers (RPTKA) as referred to in Article 8 is a permit to employ immigrant workers." That means the business entity that wants to use TKA is not obliged to administer the permit anymore. In fact, the explanation of Article 43 paragraph 1 of the Law Number 13 of 2003 reads, "Employers who use immigrant workers must have a plan for the use of immigrant workers authorized by ministers or appointed officials." The explanation of the article intends to state that the RPTKA is a requirement to obtain a work permit. In the explanation of Article 43 paragraph 1 of the Law Number 13 of 2003, it means that the RPTKA and TKA permits are different things and RPTKA is a condition for obtaining permission.

With Article 9 of the Presidential Regulation Number 20 of 2018, the permit to employ immigrant workers (IMTA) was abolished. Even though RPTKA and IMTA are different things. Second, in Article 10 paragraph 1a of the Presidential Regulation No. 20 of 2018 it is stated, "Employers of TKA are not obliged to have RPTKA to employ immigrant workers who are shareholders who serve as members of the Board of Directors or members of the board of commissioners at TKA employers." Article 42 paragraph 1 of the Law Number 13 of 2003 states, "Every employer that employs immigrant workers must have written permission from the minister or appointed official". This means that immigrant workers including commissioners and directors must have permission. Article 43 paragraph 1 explains, "Employers who use immigrant workers must have a plan for the use of immigrant workers authorized by ministers or appointed officials." It also means that RPTKA is mandatory. So, Article 10 paragraph 1a contradicts Article 42 paragraph 1 and Article 43 paragraph 1 of the Law Number 13 of 2003. Third, Article 10 paragraph 1c of the Presidential Regulation Number 20 Year 2018 states, "TKA employers are not required to have RPTKA to employ immigrant workers who are TKA on the type of work needed by the government."

In the article above means that there are exceptions for TKA employers not to take care of the RPTKA. Besides Article 43 paragraph 3 of the Law Number 13 of 2003 
which contains, "The provisions referred to in paragraph (1) do not apply to government agencies, international agencies and representatives of immigrant countries." That is, except for government agencies, international agencies, and representatives of immigrant countries. The term "government agency" means immigrant workers who work for government agencies. Article 10 paragraph 1c opens space for immigrant workers who work outside of government agencies without being required to have RPTKA. The presence of this article was allegedly devoted to immigrant workers involved in the construction of infrastructure financed by immigrant loans.

In Article 10 paragraph 1c contradicts Article 43 paragraph 3 of the Law Number 13 of 2003, it means that the presence of TKA in accordance with the Law Number 13 of 2003 concerning Manpower is the transfer of jobs and transfer of knowledge. This is the basic understanding that must be held by legislators. In addition, the Law No. 13 of 2003 expressly prohibits unskilled labor workers from working in Indonesia, except those who have skills such as high-tech engineers, international law experts, international accounting, and others. That is also with the condition that this TKA must be able to speak Indonesian, one TKA accompanied by 10 domestic workers, and there is a transfer of knowledge and transfer of jobs.

The fact revealed in the field was different from what was supposed to be mandated by the Presidential Regulation. Laode said that many immigrant workers were found working as unskilled laborers, such as goods transport drivers. Many of these TKA were found in Morowali, Central Sulawesi. "In Morowali alone, there were around 200 people who were drivers, who took the car," he said. "Generally, in the field, immigrant workers should have the most green hats and red hats. But it turns out $90 \%$ more are yellow hats. On the field. That's a significant difference," 2

On April 24, 2018, Commissioner of the Ombudsman Republic Indonesia (ORI), Laode Ida at a press conference at the Ombudsman office in Jakarta said that he found salary differences between immigrant workers and domestic workers, the Ombudsman state that immigrant workers working in Indonesia are paid three times more that domestic workers. $^{3}$

But on the other hand, the government thinks that the Presidential Regulation number 20 of 2018 is expected to encourage investment in this era of the fourth industrial revolution, or commonly called industry 4.0. President Joko Widodo (Jokowi) stated that the purpose of the issuance of the Presidential Regulation Number 20 Year 2018 concerning the Use of Immigrant Workers (TKA) is to attract many immigrant

\footnotetext{
${ }^{2}$ Marlinda Oktavia Erwanti- detikNews "Ombudsman: Banyak TKA Asal China Jadi Buruh Kasar" https://news.detik.com/berita/d-3992779/ombudsman-banyak-tka-asal-china-jadi-buruh-kasar accessed on 05 may 2018, 21.00

${ }^{3}$ Nuruliyah, Fitriyanti, "Permudah Tenaga Kerja Asing Bekerja di Indonesia, DPRD: Kebijakan yang Kurang Tepat" http://www.tribunnews.com/nasional/2018/04/26/terungkap-gaji-tenaga-kerja-asing-tigakali-lipat-pekerja-lokal-dan-tidak-terkena-pajak accessed on 05 may 2018, 21.00
} 
investors. " Immigrant Workers Permit (TKA) is easier to boost immigrant investment in the country," Jokowi said ${ }^{4}$

The Presidential Decree number 20 of 2018 signed by Indonesian President Joko Widodo on March 26, 2018 and announced by the Minister of Justice and Human Rights Yasonna Laoly on March 29, 2018. This decision raises controversies that are deemed inaccurate and violate rights domestic workers or Indonesian Workers. The Presidential Regulation Number 20 of 2018 concerning the Use of Immigrant Workers which causes the emergence of impacts on Indonesian Workers. This focus is on the Presidential Regulation number 20 of 2018 and the effects given to Indonesian Workers by the Presidential Regulation number 20 of 2018 concerning the Use of Immigrant Workers.

\section{Method}

The research method is a way to obtain data with the needs and objectives of research in questions. This study uses qualitative legal research which mainly defends on secondary data. The type of this research is under normative legal research with a statue approach and case appraisal. This study uses the provisions of the most important legal issues that arise from reality in society. Whereas the provisions of existing laws and regulations, the researchers must refer to the principles of law (or "The Principles of Law") or in the Dutch language is called "Beginsel".

Method of collecting data in this research will be through library research by literature learning. This method will collect data by reading materials at library and try to conclude from related documents such as convention, books, scientific journals, and others which related to The Presidential Regulation Number 20 of 2018 concerning The Use of Immigrant Worker; where the use of immigrant worker in Indonesia is the main problem as the object of this research.

The data were analyzed systematically through a qualitative juridical approach. Systematically through evaluation. Juridical qualitative means that it would relate to the principle of law, convention, and other regulation. So that can be systematic, qualitative, and comprehensive, illustrating the facts that are valid and related to prevailing law.

\section{Analysis and Result}

\subsection{Matters Stipulated by The Presidential Regulation Number 20 of 2018 About the Use of Immigrant Workers}

In regulating the state of life, a state law should have a strong and clear basic law. In the view of a democratic political system, legal products have believed and

\footnotetext{
${ }^{4}$ Ari Nursanti, "Perpres Tenaga Kerja Asing Untuk Tarik Investasi" https://www.pikiranrakyat.com/nasional/2018/04/12/perpres-tenaga-asing-untuk-tarik-investasi-422715 accessed on 24 July $2019,09.00$
} 
accommodated the values of Human Rights (HAM). ${ }^{5}$ One example of human rights that must be upheld is formulated in the 1945 Constitution Article 27 paragraph (2) which states that "every citizen has the right to work and a decent living for humanity". This article emphasizes that the state represented through its governmental organs must provide decent jobs for the people of Indonesia.

One of the problems that occurs in Indonesia is the problem of unemployment that occurs as well as the availability of employment for domestic workers. The government has an effort in tackling the problem of unemployment and the availability of employment for domestic workers including issuance by the President through the Presidential Regulation Number 20 of 2018 concerning Immigrant Workers. The Presidential Regulation is expected to support the national economy and expand employment opportunities through increased investment. In the previous administration when Susilo Bambang Yudhoyono served as The President of the Republic of Indonesia he issued The President Regulation Number 72 of 2014 concerning the Use of Immigrant Workers with the same considerations with the Presidential Regulation Number 20 of 2018. The Presidential Regulation Number 72 of 2014 was revoked and no longer valid after the enactment of the Presidential Regulation Number 20 of $2018 .^{6}$

In the Presidential Regulation Number 72 of 2014 concerning the Implementation of Education and Training of Assistance Workers needs to be adjusted to the development of the need for increased investment. Therefore, the regulation on the use of immigrant workers is needed and updated to the Presidential Regulation Number 20 of 2018 concerning Use of Immigrant Workers, in addition to the regulation of relicensing the use of immigrant workers is needed to support the national economy and expand employment opportunities through increased investment.

There are several ways to increase investment, one of which is to facilitate licensing the use of immigrant workers. With this Presidential Regulation, the interest is to support the growth of foreign investment into the country; this is because most immigrant investors only want to invest their funds on condition that they allow experts from the country of origin to participate in managing investment funds. In a statement from Indonesian President Joko Widodo stating that the ease of granting permits for immigrant workers was aimed at increasing the amount of immigrant investment in the country. $^{7}$

With the development of economic achieved by a country, there are also more employment opportunities available for workers both domestic and immigrant workers.

\footnotetext{
${ }^{5}$ A. Mahsyur Effendi, T. S. (2013). HAM Dalam Dinamika/Dimensi Hukum, Politik, Ekonomi, dan Sosial. Bogor: Ghalia Indonesia.P 63

6 Andri Donnal Putera, "Perpres TKA Hanya Permudah Prosedur Izin, Syarat Tidak Dikurangi" https://ekonomi.kompas.com/read/2018/04/23/202630026/perpres-tka-hanya-permudah-prosedurizinsyarat-tidak-dikurangi accessed on 1 Januari 2019, 20.00

7 BBC NEWS, "Apa di balik simpang siur Peraturan Presiden tentang tenaga kerja asing?" https://www.bbc.com/indonesia/indonesia-43872117 accessed on 27 Maret 2019, 19.00
} 
This is because the supply will always create the number of requests or supply create its own demand. But in terms of the use of immigrant workers in Indonesia has pros and cons among the people of Indonesia. Wherein the Presidential Regulation Number 20 of 2018 concerning The Use of Immigrant Workers is in accordance with considerations that consider national economic growth and employment through increasing investment.

The President has the authority in the formation of a legal product, this is a form of attribution authority given by the Constitution. This is as implied from the formulation of Article 4 paragraph (1) which reads "Presiden Republik Indonesia memegang kekuasaan Pemerintahan Menurut Undang-Undang Dasar (The President of the Republic of Indonesia holds the authority of the Government according to the Basic Law)"; the existence of this formulation has implications for the president's authority which extends the strict legislation in which the President is allowed to make and issue legal products. This provision is also explained in Article 5 Paragraph (1) "Presiden berhak mengajukan rancangan undang-undang kepada Dewan Perwakilan Rakyat (President is entitled to propose draft laws to the House of Representatives)", and in Article 22 Paragraph (1) "Dalam hal ihwal kegentingan yang memaksa, Presiden berhak menetapkan peraturan pemerintah sebagai pengganti undang-undang (In matters of urgency, the President has the right to set government regulations in lieu of laws)". In addition, related to the authority of the President in the issuance of the Presidential Regulation is a form of realization of the implementation of governmental power as formulated in Article 4 Paragraph (1) of the 1945 Constitution. $^{8}$

In forming Regulations, the President must obey the signs contained in Law Number 12 of 2011 concerning the Formation of Regulations of Article 13 which regulate that the substance of the Presidential Regulation contains material ordered by the Law. Therefore, the substance of the Presidential Regulation must be based on and derived from the above legal norms, the establishment of the Presidential Regulation is intended to implement the above legal rules. In Law Number 12 of 2011 concerning Formation of Regulations and Regulations, Article 1 paragraph (6) of the Presidential Regulations is legislation determined by the President to carry out higher statutory orders or in carrying out governmental powers.

From the Law Number 15 of 2019 concerning Amendment to the Law Number 12 of 2011 concerning the Formation of Regulations can be concluded that the Presidential Regulation is a regulation determined by the president to carry out higher regulations. In addition, the hierarchy of the regulations as referred to in the Law Number 15 of 2019 Article 7 Paragraph (1) includes:
a. UUD 1945
b. TAP MPR
c. Legislation

\footnotetext{
${ }^{8}$ Asshiddiqie, J. (2010). Perihal Undang-Undang. Jakarta: Rajawali Pres. P 152
} 
d. Government Regulation

e. The Presidential Regulation

f. Provincial Regulation

g. Regency Regulation

The legal basis of the Presidential Regulation Number 20 Year 2018 concerning The Use of Immigrant Workers includes:

1. Article 4 paragraph (1) of the 1945 Constitution of the Republic of Indonesia

2. Law Number 3 of 1951 concerning the Declaration of the Enactment of the Labor Inspection Act of 1984 Number 23 of the Republic of Indonesia for All of Indonesia

3. Law Number 13 of 2003 concerning Employment

4. Law Number 25 of 2007 concerning Investment

5. Law Number 6 of 2011 concerning Immigration

6. Presidential Regulation Number 91 of 2017 concerning the Acceleration of Business Implementation.

\subsection{History of The Presidential Regulation Number 20 of 2018 Concerning The Use of Immigrant Workers}

The Presidential Regulation Number 20 Year 2018 regarding The Use of Immigrant Workers has factors which are the impact of the emergence of this Regulation, which include:

1. Internal factors

In internal factors that influence the existence of the Presidential Regulation Number 20 Year 2018 are the government assesses to facilitate the licensing of immigrant workers, this is to increase investment figures. This presidential regulation also replaces the previous presidential regulation, the Presidential Regulation Number 72 of 2014 concerning the Use of Immigrant Workers created when Susilo Bambang Yudhoyono served as President of Indonesia at that time. According to Ridwan, a permit is a juridical instrument used by the government to influence the community to follow the method recommended by the government, so that a concrete goal is achieved. ${ }^{9}$ In general, the purpose of licensing are:

a. To control and direct certain activities, such as building permits.

b. To permits prevent danger to the environment, such as environmental permits.

c. To protect certain objects, such as permission to fly.

\footnotetext{
${ }^{9}$ Ridwan, H. (2010). Hukum Administrasi Negara. Bandung: Mandar Maju. P 11
} 
d. Permits want to divide up a few items, such as permits for residents in densely populated areas.

e. Permission provides direction by selecting people and activities, such as permits for which management must meet certain conditions (drank en horecawet).

There is a permit that regulates the people in a country. Not only regulating internal parties, it also regulates external parties entering and / or want to come to Indonesia. As is the case with licensing on immigrant workers. The presence of immigrant workers is not only concerned in terms of the impacts and positive factors caused, but also must pay attention to the importance of the impacts and negative factors caused both to impact on immigrant and domestic workers and to the country so that licensing is determined to provide legal certainty.

Besides creating immigrant employment needs to be provided from increased investment because investment is needed because the State Budget (APBN) is limited is not enough just from the state budget to create employment. There are three issues on labor in Indonesia that Hanif Dhakiri said as the minister of labor in 2018 during a discussion at the Merdeka Barat Forum, the Ministry of Communication and Information, which included quality, quantity, and distribution. Said Hanif "on the quality of workers in Indonesia, we have quality but only limited to role models". Where the role models in workers in Indonesia that are intended are the seeds of workers and have proven capabilities in certain fields both nationally and internationally. According to Hanif Dhakiri's views on three labor issues in Indonesia, Indonesia is still lacking in terms of quantity and distribution. ${ }^{10}$

The number of role models in the domestic worker is still small and cannot meet labor needs when investors want to invest in Indonesia. Therefore, the government must increase local labor competition through various programs, one of which is through immigrant workers, so that it will have an impact to facilitate investment in Indonesia.

\section{External factors}

External factors that influence the issuance of the Presidential Regulation Number 20 of 2018 are found in the Ratification of ILO Convention No. 19 concerning Equal Treatment of National and immigrant workers in the Case of Work Accident Benefits (declared valid for Indonesia with State Gazette number 53 of 1929). At the International Labor Organization general conference after its promulgation in Geneva by the Governing Body of the International Labor Office; and after holding the 7th session on the 19th May 1925, also after deciding to accept a number of proposals regarding equal treatment for national and immigrant workers in the case of accident benefits which are included in the 2nd agenda of the session agenda. Then after stipulating that these proposals must take the form of an International Convention,

\footnotetext{
${ }^{10}$ Andri Donnal Putera, "Menaker Jelaskan Mengapa Indonesia Masih Butuh Tenaga Kerja Asing" https://ekonomi.kompas.com/read/2018/04/23/204120126/menaker-jelaskan-mengapa-indonesia-masihbutuh-tenaga-kerja-asing accessed on 17 June 2019, 16.00
} 
accepting on June 5, 1925 this Convention could be called the Convention on Equal Treatment (Accident Benefits), then to be ratified by members of the International Labor Organization in accordance with the provisions of the Constitution of the Labor Organization International written in Article 1, speaking of each member of the International Labor Organization which ratifies this convention will guarantee that the citizens of every other member who has ratified this convention, regarding work accidents occurring within its territory (or each region) or the dependents are given the same treatment in terms of work accident benefits.

In controlling to optimize the use of immigrant workers in Indonesia, issuing permits must be based on clear and realistic reasons so that employers who will employ immigrant workers must have a RPTKA which is an instrument of control over the use of immigrant workers which contains the reasons for using them, the position of them, the appointment of Indonesian Workers as a companion of immigrant workers employed, and the duration of using them.

Indonesia has a labor law in the Law Number 13 of 2003 concerning Labor. In addition, the government continues to issue regulations that change but have the same basis; where basically the regulations on labor require licenses, which include the following permits:

a. Employer of immigrant workers

Some institutions that have the right to use or employ immigrant workers include:

1) Government agencies.

2) International bodies.

3) Representatives of immigrant countries.

4) International organization.

5) Immigrant company representative offices, immigrant news representative offices, and offices of immigrant trade representatives.

6) Immigrant private companies, and immigrant business entities registered with the competent authority.

7) Legal entity established under Indonesia law in the form of a Limited Liability Company or Fondation.

8) Social, religious, educational, and cultural institutions.

9) Impresario service business.

b. Planned Use of Immigrant Workers (RPTKA)

Not only plans for the use of immigrant workers in certain positions created by employers for a certain period and approved by the Minister or appointed official. But 
also, the RPTKA is a preliminary document that is used as a basis for obtaining a Permit for Using Immigrant Workers (IMTA).

c. Permission to Use Immigrant Workers (IMTA)

In the Minister of Manpower Regulation number 16 of 2015 has canceled the work visa recommendation letter. This has an impact on the RPTKA process, where after the planned use of immigrant workers submitted by the employer is approved, it can immediately proceed to the IMTA submission process; as a basis for the issuance of work visas and Limited Stay Permit Cards (KITAS) for the relevant immigrant workers.

For a long time the Indonesian government deemed it necessary to regulate the work that could be carried out by immigrant workers, this was to limit what was deemed necessary so as to provide employment opportunities for Indonesians first. ${ }^{11}$ Law Number 13 of 2003 is mandated by a separate labor inspection section for each agency responsible for labor in the Central, Provincial, and Regency / City and has the obligation to submit a report on the implementation of labor inspection to the Minister responsible for labor.

With the need for labor inspection standards that apply nationally which is carried out by the Civil Servant Investigator (PPNS) for the professionalism of the labor inspector if a violation occurs such as:

1. Employ immigrant workers without an IMTA. Although the workforce is legally entered both with a business visa, a tourist visa and a visitor visa several times.

2. Employ a immigrant worker in a position or occupation that is not in accordance with the position or occupation listed in the IMTA.

3. Legally importing immigrant workers into Indonesia.

Implementation of supervision of the use of immigrant workers can be done functionally, by way of Employee Inspection Employees (PPK) in each region. In addition, coordination was also carried out through the Interagency Supervisory Agency (SIPORA) involving the Directorate General of Immigration, the local Regional Government, the Ministry of Labor and Transmigration, the Police, and other relevant agencies.

\subsection{The Impacts Caused by the Stipulation of The Presidential Regulation Number 20 of 2018 About the Use of Immigrant Workers}

From a legal point of view, there is an article in the Presidential Regulation Number 20 Year 2018 that is contrary to legal norms as stated by Timboel Siregar, the Secretary General of the All Indonesian Workers' Organization (OPSI). There are many articles in the Presidential Regulation Number 20 of 2018 that contradict the Labor Law so that it is considered as a mistake and error. Therefore, a comprehensive evaluation is

\footnotetext{
${ }^{11}$ Law number 3 of 1958 concerning the Placement of Immigrant Workers, LN No. 8 Tahun 1958, General Explanation
} 
needed to equalize other legal regulations based on the basic norms of the truth of the Pancasila values so that the constitutional mandate can be realized properly and measures to improve the protection of local labor in Indonesia can be achieved.

The Presidential Regulation Number 20 Year 2018 regarding immigrant workers has indicators explicitly ordered or delegated, which reflects the contents of PUU and there are no abbreviations and acronyms in the title of this Presidential Regulation. Article 49 of the Law Number 13 of 2003 states that the provisions concerning the use of immigrant workers and the implementation of education and training of counterpart workers are regulated through a Presidential Decree. Whereas the Presidential Regulation Number 20 of 2018 has the title on the use of immigrant workers, although in this Presidential Regulation there is a regulation concerning the implementation of education and training of companion workers.

In the development of the issuance of the Presidential Regulation Number 20 of 2018, it has raised criticisms and other problems that have arisen due to the existence of several articles contained in this Regulation; where in the use of Immigrant Workers which worsens the availability of jobs in Indonesia. In addition, there are gaps between immigrant workers and domestic workers in Indonesia and in several articles have adverse consequences for the rights of domestic workers. The articles contained in the Presidential Regulation Number 20 of 2018 which caused new problems include:

1. Article 9 which reads "Pengesahan RPTKA sebagaimana dimaksud dalam pasal 8 merupakan izin untuk memperkerjakan TKA (Ratification of the RPTKA as referred to in article 8 is a permit to employ TKA)"”.

Arrangements regarding the same authority in two or more PUUs with different hierarchies but implemented by different institutions in Article 8 of the Presidential Regulation Number 20 Year 2018. In this article the ratification of the Plan for the Use of Immigrant Workers (RPTKA) is granted by the Minister or official appointed no later than two days after the application is received in full. With the ratification of the RPTKA according to Law Number 13 of 2003 concerning Labor Article 43 paragraph (4) states that the Minister has the authority to determine the rules for the ratification of the RPTKA; whereas in the Presidential Regulation Number 20 Year 2018 Article 8 states that the ratification of the RPTKA is made by the Minister or appointed official.

The Plan for the Use of Immigrant Workers (RPTKA) in this Presidential Regulation is as a permit to employ Immigrant Workers, as described in the words "constitute permission to employ Immigrant Workers". Plans for the use of immigrant workers in certain positions made by the employer who have a certain time limit in which the RPTKA must be submitted and get authorization from the Minister or relevant officials.

With the existence of the Plan for the Use of Immigrant Workers (RPTKA) as a permit to employ Immigrant Workers has an impact on controversy in the community because the requirements for hiring Immigrant Workers are simpler and easier. The 
formulation of Article 9 in the Presidential Regulation Number 20 of 2018 shows that there is an asynchrony in the regulation of permission to use TKA. In the Labor Law the Permit for the Use of Immigrant Workers is contained in Article 42 paragraph (1) which reads "Every employer who employs immigrant workers must have written permission from the Minister or a designated official", this formulation implies that the RPTKA is only part of the requirements that must be fulfilled to obtain permission; RPTKA is not interpreted as a permit to employ immigrant workers so it is clear that Article 9 of the Presidential Regulation on Immigrant Workers violates articles in the Labor Law. By given the facts that have been described, the implication that arises is the Ease of Immigrant Workers to expand in Indonesia.

Based on the Labor Law in Article 43 paragraph (1) states "Pemberi kerja yang menggunakan tenaga kerja asing harus memiliki rencana penggunaan tenaga kerja asing yang disahkan oleh Menteri atau pejabat yang ditunjuk (Employers using immigrant workers must have a plan for the use of immigrant workers that is approved by the Minister or appointed official)". In the explanation contained in Article 43 paragraph (1) it also explains that the Plan for the Use of Immigrant Workers (RPTKA) is a requirement for obtaining a Immigrant Workers work permit. In the formulation of this article it is known that the RPTKA is one of the requirements that must be met in order to obtain a permit to employ Immigrant Workers and not be interpreted as a permit to employ Immigrant Workers.

Work Permit for Immigrant Workers is sufficient with IMTA only, which includes RPTKA as an attachment but the RPTKA does not need to be formalized by the Ministry of Labor. This has an impact on all workers including directors or commissioners who need or have a work permit. Deputy Chairman of the House of Representatives Commission IX, Saleh Daulay said that this regulation tends to facilitate the entry of immigrant workers into Indonesia, while many domestic workers require employment. He also said that he understood that the Indonesian government needed Immigrant Workers to attract investment and experts to Indonesia.

According to Saleh Daulay, Chairman of Commission IX of the Republic of Indonesia House of Representatives, the Presidential Regulation Number 20 of 2018 will have a negative impact caused by facilities for immigrant workers; other than that the government's limited ability to supervise or monitor will be more difficult. Not only that, according to Saleh there is also no guarantee of Immigrant Workers who increase investment numbers and create jobs in Indonesia. ${ }^{12}$ While the government is responsible for the unemployment rate in Indonesia. Therefore, if a Immigrant Worker is made easier in terms of permits to enter and work in Indonesia, the problem of unemployment in Indonesia has not been resolved. It would be better if immigrant investors and Immigrant Workers enter Indonesia and recruit domestic workers.

\footnotetext{
12 Indopos, "Perpres TKA Timbulkan Dampak Negatif" https://indopos.co.id/read/2018/04/06/133847/perpres-tka-timbulkan-dampak-negatif/ accessed on 6 April 2018. 15.30
} 
2. Article 10 paragraph (1) which reads "Pemberi Kerja TKA tidak wajib memiliki RPTKA untuk memperkerjakan TKA yang merupakan : a. Pemegang saham yang menjabat sebagai anggota Direksi atau Anggota Dewan Komisaris pada Pemberi kerja TKA; b. Pegawai diplomatik dan konsuler pada kantor perwakilan negara asing; atau c. TKA pada jenis pekerjaan yang dibutuhkan oleh pemerintah (The TKA Employer is not required to have a RPTKA to hire a TKA which is: a. Shareholders who serve as members of the Board of Directors or Board of Commissioners of a TKA employer; $b$. Diplomatic and consular staff at representative offices of immigrant countries; or c. TKA on the type of work needed by the government)".

The formulation of Article 10 has an adverse indication for domestic workers because the RPTKA contained in the Presidential Regulation Number 20 of 2018 is interpreted as a permit to employ Immigrant Workers and is only a matter of volunteerism for the classification of Immigrant Workers described in Article 10. In addition to the exceptions contained in Article 10 is a manifestation of the expansion of the provisions stipulated by the Labor Law Article 43 paragraph (3) which stipulates that the preparation of the RPTKA does not apply to government agencies, international agencies, and representatives of immigrant countries.

Expansion of this regulation will create new problems in terms of labor in Indonesia, including the number of Immigrant Workers will increase, job opportunities will be reduced, and the government monitoring mechanism for new arrivals will be weak. In Article 10 paragraph (1) which contains the obligation to have an RPTKA to employ Immigrant Workers who are qualified to have an impact on the exact duration of work in Indonesia for the position held. ${ }^{13}$

There is a strong potential for discrimination in the Presidential Regulation Number 20 of 2018 Article 10. If it is distinguished because the basis for using a Immigrant Worker is in the RPTKA to find out the purpose and direction of the use of Immigrant Workers, while the current process no longer requires a long time. It only takes two days so that obstacles in the field can be minimized. The government should pay more attention to the procedures for the entry of Immigrant Workers into Indonesia. The limitation of Immigrant Workers by the procedure for entering Indonesia through the Presidential Regulation Number 20 of 2018 must be clear and clarity is needed.

3. Article 19 which reads "Pejabat imigrasi pada Perwakilan Republik Indonesia di luar negeri memberikan Vitas Paling lama 2 (dua) hari sejak Permohonan di terima secara lengkap (Immigration officials at Representatives of the Republic of Indonesia abroad provide Vitas no later than 2 (two) days from receipt of complete applications)".

\footnotetext{
13 Kompas, "Pemerintah Siapkan Aturan Turunan Perpres Tenaga Kerja Asing", https://biz.kompas.com/read/2018/04/18/161326328/pemerintah-siapkan-aturan-turunan-perpres-tenagakerja-asing accessed on 29 Maret 2019. 13.28
} 
Limited Stay Visa (Vitas) is a written statement containing approval for foreigners to travel to Indonesia and is the basis for granting a limited stay permit to work in Indonesia. ${ }^{14}$ Under the Labor Law Articles 42 and 43, companies wishing to use a Immigrant Worker must have written permission from the Ministry of Labor or a designated official, and an RPTKA approved by the Minister of Labor or a designated official; except for representatives of immigrant countries that use immigrant workers as diplomatic and consular employees.

4. Article 26 paragraph (1) which reads "Setiap pemberi Kerja TKA Wajib : a. menunjuk tenaga kerja indonesia sebagai tenaga kerja pendamping; $b$. Melaksanakan pendidikan dan pelatihan bagi tenaga kerja indonesia sesuai dengan kualifikasi jabatan yang diduduki oleh TKA;dan c. Memfasilitasi pendidikan dan Pelatihan Bahasa Indonesia Kepada TKA (Every TKA Employer Obligatory: a. appoint Indonesian workers as companion workers; b. Carry out education and training for Indonesian workers in accordance with the qualifications of positions occupied by TKA, and c. Facilitating Indonesian education and training for TKA)".

The problem contained in the formulation of Article 26 paragraph (1) is the neglect of the main objective of this Immigrant Worker working in Indonesia. The main purpose of Immigrant Workers to work in Indonesia is none other than to teach science and technology in Indonesia. This main objective is neglected because in this article only explains the obligations of employers of Immigrant Workers and does not provide obligations to Immigrant Workers to teach either science or technology so that the Presidential Regulation Number 20 of 2018 is unable to respond to the needs in the exchange of knowledge and technology for domestic workers.

Based on the Law Number 25 of 2007 concerning Investment Article 10, investment companies are entitled to use Immigrant Workers for certain positions and expertise in accordance with statutory provisions while continuing to prioritize domestic workers in meeting the needs of workers so that investment companies are required improve the competency of domestic workers through job training in accordance with statutory provisions. Investment companies that employ Immigrant Workers are also required to conduct training and transfer technology to domestic workers.

Employment opportunities for all Indonesian people are rights guaranteed by the state because of the right of citizens to meet the needs for life, both for their own needs and the needs for others. This has been regulated in several regulations including:

a. In the constitution in Article 27 paragraph (2) of the 1945 Constitution, which reads "that every citizen has the right to work and a decent living for humanity". It is

14 Linda Teti Silitonga, "Tanaga Kerja Asing: Soal Vitas, Ini Kata Bpjs Watch", https://ekonomi.bisnis.com/read/20180405/12/780575/tanaga-kerja-asing-soal-vitas-ini-kata-bpjs-watch, accessed on 29 Maret 2019, 13.35 
stated clearly that in terms of getting opportunities for jobs that produce decent livelihoods become basic rights or human rights guaranteed by the state.

b. In the Universal Declaration of Human Rights of 10 December 1948 which was accepted and announced by the UN General Assembly on 10 December 1948 article 23 stated:

1) Everyone has the right to work, has the right to freely choose work, has right to fair and good labor conditions, and to protection against unemployment.

2) Everyone with no difference is entitled to the same remuneration for the same job.

3) Every person who does work is entitled to a good and kind remuneration.

c. In the consideration of Law Number 13 of 2003 concerning Labor stated that the protection of workers is intended to guarantee the basic rights of workers and ensure equal opportunity and treatment without discrimination on any basis to realize the welfare of workers while still taking into account developments in the progress of the business world.

Job opportunities are one of the things that affect employment because not only are job opportunities a basic human need that can be equated with the needs of clothing, food, and housing. In addition, employment opportunities also become one of the economic indicators that can be used to measure the success of an area that can be seen through the level of community participation in a country to develop the economy; employment opportunities can also be used to assess the level of success of the government in meeting or implementing a country's economic policies.

\subsection{Immigrant Workers During the Covid-19 Pandemic}

Since the first case of a corona virus patient in Indonesia was reported on March 2, 2020, Indonesia faced Covid-19, which according to the WHO has become a pandemic where pandemic means outbreaks that are simultaneously contagious due to the spread of new diseases in various regions covering large geographical areas. Besides, it is obvious because Covid-19 has an impact on the health sector, but not only on the health sector; also affects the economic sector, especially on the survival of workers and income.

Countries that depend on tourism and commodity exports face high economic risks as well as developing countries like Indonesia. Global manufacturing production can have a significant impact, while decreases in income related to capital and commodity reversals increase to cause debt pressure for some countries. The steps the government can take is that the government may be forced to limit public spending when it is needed to increase spending to overcome this pandemic and support consumption and investment, especially in Indonesia. 
The economy that is now becoming unstable due to Covid-19 has affected the workers not only in Indonesia but in other countries. At present, DKI Jakarta is assumed to be the region worst affected, followed by West Java and other Provinces on the island of Java. Data from the Ministry of Labor as of April 20, 2020 recorded 2,084,593 workers from 116,370 companies affected by Termination of Employment (PHK). That is because several companies experienced a decline in production and even stopped producing. ${ }^{15}$

There are 500 immigrant workers from China will enter the Southeast Sulawesi region. The immigrant workers are planned to work at PT Virtue Dragon Nickel Industry and PT Obsidian Stainless Steel in Southeast Sulawesi. The arrival of the immigrant workers from China has been approved by the central government. However, the Governor of Southeast Sulawesi and the Southeast Sulawesi Regional Leadership Coordination Forum including the Southeast Sulawesi Regional Representative Council, Danrem, Kapolda, until the immigration authorities refused the arrival of the immigrant workers. The rejection was made because of the Covid-19 pandemic and so that the pandemic did not spread more. The Chairperson of the Southeast Sulawesi Legislative Council, Abdurrahman Shaleh, stated that the rejection did not mean anti-Chinese investment, but because of the current situation which was caused by the Covid-19 pandemic. ${ }^{16}$

The Ministry of Manpower (Kemenaker) revealed that granting licenses to PT Virtue Dragon Nickel Industry and PT Obsidian Stainless Steel in Southeast Sulawesi to bring in 55 immigrant workers for various considerations. One consideration is that domestic workers avoid termination of employment (PHK), said Director General Binapenta and PKK Kemenaker Aris Wahyudi. The MoM sees a huge potential for layoffs if the company is unable to operate again. ${ }^{17}$

The House of Representatives Commission X member Saleh Partaonan Daulay criticized the government's policy of granting entry permits for immigrant workers from China to Southeast Sulawesi amid the Covid-19 pandemic situation. Saleh said the policy made the Indonesian government look very inferior when dealing with the Chinese investor. Not only that, Saleh also said that the arrival of immigrant workers to Indonesia at a time when Indonesian citizens needed work caused by the Covid-19 pandemic was considered inappropriate. The arrival of immigrant workers to Indonesia is considered inappropriate because it will cause feelings of worry and fear for the

\footnotetext{
15 Biro Kerja Sama, Hukum, dan Humas LIPI, "Dampak Darurat Virus Corona terhadap Tenaga Kerja Indonesia", http://lipi.go.id/berita/Dampak-Darurat-Virus-Corona-terhadap-Tenaga-KerjaIndonesia/22034, accessed on 10 juli 2020, 15.30

${ }^{16}$ Rachmawati, "Saat 500 TKA Asal China Akan Didatangkan di Tengah Pandemi Corona, Klaim untuk Hindari PHK Pekerja Lokal”, https://regional.kompas.com/read/2020/05/03/06400071/saat-500-tka-asalchina-akan-didatangkan-di-tengah-pandemi-corona-klaim?page=all, accessed on 13 juli 2020, 15.35

${ }_{17}$ Ade Miranti Karunia, "Kemenaker: Izin 500 TKA China Diberikan untuk Menghindari PHK Pekerja Lokal", $\quad$ https://money.kompas.com/read/2020/05/02/200200726/kemenaker--izin-500-tka-chinadiberikan-untuk-menghindari-phk-pekerja-lokal?page=all\#page2, accessed on 13 Juli 2020, 15.45
} 
community because it has a high potential in the spread of the corona virus. In addition, Saleh also requested that the central government listen and fulfill the aspirations of the Southeast Sulawesi DPRD related to the rejection of immigrant workers. ${ }^{18}$

These aspirations and rejections are for the handling of the Covid-19 pandemic which is supported by an increasing number of positive patients with Covid-19 and still has not shown a decrease in the number of positive patients or died due to corona virus.

The Indonesian government does not prohibit the entry of immigrant workers into Indonesia. The government has determined the requirements stipulated in the Labor Law Number 13 of 2003, The Presidential Regulation Number 20 of 2018, and The Minister of Labor Regulation Number 10 of 2018. These regulations are intended to prevent the entry of illegal immigrant workers who do not follow procedures predefined. Where the presence of immigrant workers in Indonesia to teach domestic workers in the field of technology and knowledge which will replace the role of immigrant workers.

These regulations have a weakness where these regulations provide opportunities for companies that employ immigrant workers to excuse because domestic workers do not meet the qualifications required by the company. Therefore, this opportunity must be carried out in line with the transfer of technology from immigrant workers to Indonesian counterpart workers and with the "new normal" stages imposed by the government in order to harmonize the economy with the Covid-19 situation, it must be anticipated and well prepared because if immigrant workers have been determined allowed to enter Indonesia.

The presence of immigrant workers from various countries must certainly be considered by the Indonesian government; so that the presence of immigrant workers should not bring new problems to the development of companies, domestic workers, and the people of Indonesia. Therefore, several things need to be considered so as not to occur or minimize the negative impacts caused by the entry of immigrant workers into Indonesia, which include:

1. The implementation of the Health protocol for immigrant workers, this is to prevent the transmission and spread of Covid-19 in entering the new normal period.

2. Immigrant workers entering Indonesia must be accompanied by a health certificate free of Covid-19 from the country's Health authority.

3. Immigrant workers must be prepared to be quarantined for 14 days which is carried out and supervised by the authorities of the Indonesian government or can be quarantined in other countries that are not infected by Covid-19 before entering Indonesia.

\footnotetext{
${ }^{18}$ Maria Arimbi Haryas Prabawanti, "Terima TKA China di Tengah Pandemi, Komisi X DPR: Bukti Pemerintah Inferior dengan Investor", https://nasional.kompas.com/read/2020/04/30/19131981/terimatka-china-di-tengah-pandemi-komisi-x-dpr-bukti-pemerintah-inferior, accessed on 13 Juli 2020, 15.50
} 
With the existence of the new normal President Joko Widodo hopes that people can make peace with Covid-19. Where the intention of President Joko Widodo in inviting people to make peace with Covid-19 is that the community remains productive even though this pandemic is still endemic in Indonesia making adjustments in life, this has been explained by the Deputy for Protocol, Press, and Media of the Presidential Secretariat Bey Machmudin. Bey Machmudin said that until now antivirus for Corona Virus has not yet been found, but the community can prevent transmission by applying health protocols such as using masks, diligently washing hands with soap, and maintaining distance both social distance and physical distance. ${ }^{19}$

\section{Conclusion}

1. Matters arising in the Presidential Regulation Number 20 of 2018 concerning the use of immigrant workers:

a. With the Presidential Regulation Number 20 of 2018 concerning the Use of Immigrant Workers is to facilitate the licensing of immigrant workers. That is because the government assesses by facilitating the licensing of immigrant workers to increase investment; but with the convenience, it affects the domestic workers. There are 4 articles in the Presidential Regulation Number 20 of 2018 which cause problems as in Article 9 because in this article there is disharmony related to RPTKA. In this article, ratification of the RPTKA is given by the Minister or an appointed official no later than two (2) days after the application is received in full. Whereas in the ratification of the RPTKA according to the Law Number 13 of 2003 concerning Labor Article 43 Paragraph (4) states that the Minister has the authority to determine the rules for the ratification of the RPTKA.

b. In the Presidential Regulation Number 20 of 2018 Article 10 Paragraph (1) has an indication that is detrimental to the domestic worker, this is because it is considered unfair because it has a similar position in law and government. The expansion contained in Article 10 raises new problems in the field of labor in Indonesia which include the number of immigrant workers will increase, the reduction in employment, and the mechanism of government supervision of new migrants becomes weak.

c. The last article of the Presidential Regulation Number 20 of 2018 that caused another problem was Article 26 Paragraph (1), which in this article not only had a lack of monitoring and evaluation aspects, but also had a lack of effectiveness in implementation; because the problem contained in the formulation of Article 26 Paragraph (1) is the neglect of the main objective of this immigrant worker

19 Ihsanuddin, "Jokowi Sebut Hidup Berdamai dengan Covid-19, Apa Maksudnya?", https://nasional.kompas.com/read/2020/05/08/06563101/jokowi-sebut-hidup-berdamai-dengan-covid-19apa maksudnya?utm_source=Twitter\&utm_medium=Refferal\&utm_campaign=Sticky_Dekstop, accessed on 13 Juli $2020,15.50$ 
working in Indonesia. The main purpose of immigrant workers to work in Indonesia is none other than to teach science and technology in Indonesia.

2. The impact of the Presidential Regulation Number 20 of 2018 regarding using of immigrant worker to Indonesia workers are:

a. There is a lack of legal clarity that applies due to several articles in the Presidential Regulation No. 20 of 2018 that contradict the Law Number 13 of 2003 concerning employment.

b. Domestic workers feel disadvantaged because of reduced employment opportunities, as well as different treatment with immigrant workers such as the amount of salary or benefits.

c. With the lack of monitoring in accepting or entering immigrant workers can increase the number of patients with Covid-19 or accelerate the transmission of the corona virus. Therefore, with the aim of reducing the risk of transmission caused by the entry of immigrant workers into Indonesia, health protocols are needed at both workplaces and immigrant workers who will enter Indonesia. As for immigrant workers who will enter Indonesia must have a free health certificate from Covid-19 from the state health authority of the immigrant worker, and must be prepared to be quarantined for 14 days which is carried out and supervised by the authorities of the Indonesian government or can be quarantined in the territory of other countries which were not infected by Covid19 before entering Indonesia.

\section{References}

\section{Books}

Khakim, Abdul. (2009). Dasar-Dasar Hukum Ketenagakerjaan Indonesia. Bandung: Citra Aditya Bakti.

Hamzah, Andi. (1990). Pokok-pokok Hukum Ketenagakerjaan. Jakarta: Rineka Cipta.

A. Mahsyur Effendi, T. S. (2013). HAM Dalam Dinamika/Dimensi Hukum, Politik, Ekonomi, dan Sosial. Bogor: Ghalia Indonesia.

Asshiddiqie, J. (2010). Perihal Undang-Undang. Jakarta: Rajawali Pres.

Sjarif, Amiroeddin. (1987). Perundang-Undangan Dasar, Jenis, dan Teknik Membuatnya. Jakarta; Bina Aksara.

Manan, Bagir. (1992). Dasar-Dasar Perundang-Undangan Indonesia. Jakarta; Ind-HillCo.

Waluyo, Bambang. (2002). Penelitian Hukum dalam Praktek. Jakarta; Sinar Grafika. 
Kansil, CST. (1989). Pengantar Ilmu Hukum dan Tata Hukum Indonesia. Jakarta; Balai Pustaka.

Ismatullah, Dedi. (2013) Hukum Ketenagakerjaan. Bandung; Penerbit pustaka setia.

Kelsen, Hans. (1945). General Theory of Law and State. New York; Russell \& Russell.

Rusli, Hardjan. (2011). Hukum Ketenagakerjaan. Bogor; Ghalia Indonesia.

Ibrahim, Johnny. (2006). Teori dan Metodologi Penelitian Hukum Normatif. Malang; Bayu Media.

Indrati Soeprapto, Maria Farida. (2006) Ilmu Perundang-Undangan, Dasar-Dasar dan Pembentukannya. Yogyakarta; Kanisius.

Mike McConville \& Wing Hong Chui, (2012). Research Methods for Law. Edinburgh; Edinburgh University Press.

Muchsin. (2003) Perlindungan dan Kepastian Hukum bagi Investor di Indonesia. Surakarta; Universitas Sebelas Maret.

Yulianto Achmad, Mukti Fajar. (2010). Dualisme Penelitian Hukum Empiris \& Normatif. Yogyakarta; Pustaka Pelajar.

Huda, Nieematul. (2011). Teori \& Pengujian Peraturan Perundang-Undangan. Bandung; Nusamedia.

H.R, Ridwan. (2010). Hukum Administrasi Negara. Bandung; Mandar Maju.

Ranggawidjaja, Rosjidi. (1998). Pengantar Ilmu Perundang-Undangan Indonesia. Bandung; Mandar Maju.

Sri Mamudji, Soerjono Soekanto. (2007). Penelitian Hukum Normatif. Suatu Tinjauan Singkat. Jakarta; Rajawali.

Soekanto, Soerjono. (1983). Pengantar Penelitian Hukum. Jakarta; UIPers.

Setiono. (2004). Rule of Law (Supremasi Hukum). Surakarta; Magister Ilmu Hukum Program Pascasarjana Universitas Sebelas Maret.

S.Mulyadi. (2012). Ekonomi Sumber Daya Manusia dalam Perspektif Pembangunan. Jakarta; Rajawali Pers.

Tambunan. (2002). Tenaga Kerja. Yogyakarta; BPFE.

Sugiarto, Umar Said. (2013). Pengantar Hukum Indonesia. Jakarta; Sinar Grafika.

\section{Journals}

Fatkhul Muin. (2015). Perlindungan Hukum Terhadap Tenaga Kerja Indonesia. Jurnal Cita Hukum. 3(1). 
Rizky Dian Bareta and Budi Ispriyarso. (2018). Politik Hukum Perlindungan Tenaga Kerja Indonesia Fase Purna Bekerja. Kanun Jurnal Ilmu Hukum. 20(1).

Tri Listiani, dkk. (2012). Kendala Perlindungan Hukum terhadap Buruh Migran di Kabupaten Cilacap. Jurnal Dinamika 12(2).

Syaifuddin Zuhdi, Wisnu Tri Nugroho, dkk. (2019). Meninjau Peraturan Presiden Nomor 20 Tahun 2018 Sebagai Rangka Perbaikan Hukum Perlindungan Tenaga Kerja Indonesia. Law and Justice Jurnal, 4(1).

Budiarti. (2015). Prinsip Dasar Hak Asasi Manusia (HAM) Dalam Terminologi Doktrin Hukum Islam: Penelaahan Ayat Dalam Al-Qur'an Dengan Tafsir Maudhu'iy. AlMizan, 11(1).

Moch Thariq Shadiqin. (2019). Perlindungan Hukum Terhadap Tenaga Kerja Asing Berdasarkan Asas Kepastian dan Keadilan. Administrative Law \& Governance Journal. 2(3).

Devi Lestyasari. (2013). Hubungan Upah Minimum Provinsi dengan Jumlah Tenaga Kerja Formal di Jawa Timur. Jurnal Pendidikan Ekonomi, 1(3).

\section{Dissertation, Thesis, Undergraduate Thesis}

Nadiah Ardyasakina, 2018, "Implementasi Pasal 33 Peraturan Presiden Ri No. 20 Tahun 2018 Terkait Dengan Pelaksanaan Pengawasan Terhadap Penggunaan Tenaga Kerja Asing Di Kabupaten Malang", (Skripsi Sarjana Ilmu Hukum tidak diterbitkan, Universitas Muhammadiyah Malang).

Muhammad Syaifullah Khairuddin, 2019, "Pandangan Maslahah Mursalah dan Hukum Progresif Terhadap Perpres Nomor 20 Tahun 2018”, (Skripsi Sarjana Ilmu Hukum tidak diterbitkan, Fakultas Syariah Institut Agama Islam Negeri (IAIN) Surakarta).

Syeikha Nabilla, 2020, "Dampak COVID-19 terhadap Tenaga Kerja di Indonesia" (Skripsi Sarjana Pengantar Ilmu Kesejahteraan Sosial tidak diterbitkan, Universitas Padjadjaran department Social Welfare bachelor social word Bandung).

\section{Legislation}

The 1945 Constitution

The Law No. 3 of 1951 concerning the Declaration of the Enactment of the Labor Inspection Act of 1984 Number 23 of the Republic of Indonesia for All of Indonesia

The Law No. 3 of 1958 concerning the Placement of Immigrant Workers 
The Law No. 13 of 2003 concerning Employment

The Law No. 25 of 2007 concerning Investment

The Law No. 12 of 2011 concerning the Establishment of Legislation

The Law No. 6 of 2011 concerning Immigration

The Law No. 15 of 2019 concerning Amendment to the Law Number 12 of 2011 concerning the Formation of Regulations

The Presidential Regulation No. 20 of 2018 concerning the use of immigrant workers.

The Minister of Manpower Regulation No. 10 of 2018 concerning Procedures for Use Of Immigrant Workers

The Minister of Manpower Regulation No. 33 of 2016 concerning Labor Inspection Procedures

Decree of the Minister of number: KEP.100 / MEN / VI / 2004 concerning Provisions for Implementing Specific Time Work Agreements

\section{Website}

Ade Miranti Karunia, "Izin 500 TKA China Diberikan untuk Menghindari PHK Pekerja Lokal", Taken from: https://money.kompas.com/read/2020/05/02/200200726/kemenaker--izin-500-tkachina-diberikan-untuk-menghindari-phk-pekerja-lokal?page=all\#page2., accessed on 13 Juli 2020, at 15.45

Andri Donnal Putera, "Perpres TKA Hanya Permudah Prosedur Izin, Syarat Tidak Dikurangi", Taken from: https://ekonomi.kompas.com/read/2018/04/23/202630026/perpres-tka-hanyapermudah-prosedur-izinsyarat-tidak-dikurangi., accessed on 1 Januari 2019, 20,00

Andri Donnal Putera, "Menaker Jelaskan Mengapa Indonesia Masih Butuh Tenaga Kerja Asing”, Taken from: https://ekonomi.kompas.com/read/2018/04/23/204120126/menaker-jelaskanmengapa-indonesia-masih-butuh-tenaga-kerja-asing., accessed on 17 June 2019, 16.00

Ari Nursanti, "Perpres Tenaga Kerja Asing Untuk Tarik Investasi", Taken from: https://www.pikiran-rakyat.com/nasional/2018/04/12/perpres-tenaga-asing-untuktarik-investasi-422715., accessed on 24 July 2019, 11,30

Asep Jumarsa, "Peraturan Presiden No 20 tahun 2018 Tentang Tenaga Kerja Asing", Taken from: https://www.kennywiston.com/analisis-peraturan-presiden-no-20tahun-2018-tentang-tenaga-kerja-asing/., accessed on 28 Juni 2019, 18.00 
BBC NEWS, "Apa di balik simpang siur Peraturan Presiden tentang tenaga kerja asing?”, Taken from: https://www.bbc.com/indonesia/indonesia-43872117., accessed on 27 Maret 2019, 19.0

Biro Kerja Sama, Hukum, dan Humas LIPI, "Dampak Darurat Virus Corona terhadap Tenaga Kerja Indonesia", Taken from: http://lipi.go.id/berita/Dampak-DaruratVirus-Corona-terhadap-Tenaga-Kerja-Indonesia/22034., accessed on 10 juli 2020, 15.30

Fiki Ariyanti, "Ada Aturan Baru Tenaga Kerja Asing, Nasib Pekerja RI Diujung Tanduk”, Taken from: https://www.liputan6.com/bisnis/read/3469874/ada-aturanbaru-tenaga-kerja-asing-nasib-pekerja-ri-di-ujung-tanduk., accessed on 09 June $2019,14,50$.

Humas, "Peraturan Presiden Nomor 20 Tahun 2018: Ikhtiar Untuk Meningkatkan Investasi dan Perluasan Kesempatan Kerja”, Taken from: https://setkab.go.id/peraturan-presiden-nomor-20-tahun-2018-ikhtiar-untukmeningkatan-investasi-dan-perluasan-kesempatan-kerja-2/., accessed on 28 Juni, 2019, 23.00 .

Indopos, Perpres TKA Timbulkan Dampak Negatif, Taken from: https://indopos.co.id/read/2018/04/06/133847/perpres-tka-timbulkan-dampaknegatif/., accessed on 6 April 2018. 15.30

Kompas, Pemerintah Siapkan Aturan Turunan Perpres Tenaga Kerja Asing, Taken from: https://biz.kompas.com/read/2018/04/18/161326328/pemerintah-siapkanaturan-turunan-perpres-tenaga-kerja-asing., accessed on 29 Maret 2019. 13.28

Linda Teti Silitonga, Tanaga Kerja Asing: Soal Vitas, Ini Kata Bpjs Watch, Taken from: https://ekonomi.bisnis.com/read/20180405/12/780575/tanaga-kerja-asingsoal-vitas-ini-kata-bpjs-watch., accessed on 29 Maret 2019, 13.35

Maria Arimbi Haryas Prabawanti, Terima TKA China di Tengah Pandemi, Komisi X DPR: Bukti Pemerintah Inferior dengan Investor, Taken from: https://nasional.kompas.com/read/2020/04/30/19131981/terima-tka-china-ditengah-pandemi-komisi-x-dpr-bukti-pemerintah-inferior., accessed on $13 \mathrm{Juli}$ $2020,15.50$

Marlinda Oktafia, Ombudsman: Banyak TKA Asal China Jadi Buruh Kasar, Taken from: $\quad$ https://news.detik.com/berita/d-3992779/ombudsman-banyak-tka-asalchina-jadi-buruh-kasar., accessed on 05 May 2018, 17,32.

Nuruliyah, Fitriyanti, Permudah Tenaga Kerja Asing Bekerja di Indonesia, DPRD: Kebijakan yang Kurang Tepat, Taken http://www.tribunnews.com/nasional/2018/04/26/terungkap-gaji-tenaga-kerja- 
asing-tiga-kali-lipat-pekerja-lokal-dan-tidak-terkena-pajak., accessed on 05 May $2018,15,50$.

"Noname", Undang - undang Ketenagakerjaan Terbaru UU No 13 Tahun 2003 dan Klasifikasi Tenagakerja, Taken from: https://dokumen.tips/documents/bab-iitinjauan-pustaka-a-tinjauan-umum-tentang-tenaga-tentang-syarat-.html., accessed 04 Januari 2018 at 09.00

Rachmawati, Saat 500 TKA Asal China Akan Didatangkan di Tengah Pandemi Corona, Klaim untuk Hindari PHK Pekerja Lokal, Taken from: https://regional.kompas.com/read/2020/05/03/06400071/saat-500-tka-asal-chinaakan-didatangkan-di-tengah-pandemi-corona-klaim?page=all., accessed on 13 juli $2020,15.35$

Safyra Primadhyta, Momok Perpres Tenaga Kerja Asing Akibat Pengawasan Loyo, Taken from: https://www.cnnindonesia.com/ekonomi/20180501074618-92294822/momok-perpres-tenaga-kerja-asing-akibat-pengawasan-loyo., accessed on 09 June 2019, 16,60. 